\title{
Strategi Manajemen Krisis Public Relations PT Blue Bird Group
}

\author{
Ita Suryani, Asriyani Sagiyanto \\ Akademi Komunikasi Bina Sarana Informatika \\ ita.its@bsi.ac.id; asriyani.ayy@bsi.ac.id
}

\begin{abstract}
One of the activities of Public Relations is to perfom a communication function in deveoping institutional communication with the public to realize goodwill and mutual understanding. In a crisis situation, Public Relations plays a vital role. The profession demands the ability to design, to protect, and to maintain the company's reputation in the public challenge. Blue Bird's commitment to change is one of the strategies of management crisis known as the "reimagining Blue Bird" program. This program voiced through the "Blue Bird Changing To Change" campaign ad on YouTube. The purpose of this study is to know the strategies of Crisis Management of the Public Relations PT Blue Bird Group (Case Study at PT Blue Bird Group Post Demonstration Riot \& Anarchist, March 22, 2016). The method used in this research is a case study method. It uses various data sources that can be used to research, describe and explain comprehensively the various aspects of individuals, groups, programs, organizations or events systematically. The conclusion shows that the Blue Bird "reimagining" campaign program voiced through the "Blue Bird Changing To Change" campaign ad on YouTube has attracted attention and gained sympathy from the public, which in turn can build positive public opinion and impact on Blue Bird's reputation.
\end{abstract}

\section{Keyword: Public Relations Strategies, Crisis Management}

\begin{abstract}
ABSTRAK
Salah satu kegiatan dari seorang public relations yakni sebagai fungsi komunikasi untuk mengembangkan komunikasi institusi dengan publik agar berjalan dengan baik untuk mewujudkan goodwill dan mutual understanding terhadap publik. Di dalam situasi krisis, Public Relations berperan vital. Profesi tersebut dituntut kemampuan mendesain untuk melindungi dan mempertahankan reputasi perusahaan dalam menghadapi tantangan publik. Komitmen Blue Bird untuk berubah merupakan salah satu strategi manajemen krisis yang dilakukan melalui program "reimagining Blue Bird." Program ini disuarakan melalui iklan kampanye Blue Bird "Berbenah Untuk Berubah" di YouTube. Tujuan penelitian ini yaitu ingin mengetahui bagaimana Strategi Manajemen Krisis Public Relations PT Blue Bird Group (Studi Kasus Pada PT Blue Bird Group Pasca Demonstrasi Rusuh \& Anarkis, 22 Maret 2016). Metode yang digunakan dalam penelitian ini yaitu metode studi kasus yaitu metode riset yang menggunakan berbagai sumber data yang bisa digunakan untuk meneliti, menguraikan dan menjelaskan secara komprehensif berbagai aspek individu, kelompok, suatu program, organisasi atau peristiwa secara sistematis. Kesimpulan menunjukkan bahwa program kampanye "reimagining Blue Bird" yang disuarakan melalui iklan kampanye "Berbenah Untuk Berubah" di YouTube berhasil menarik perhatian dan mendapatkan simpati dari publik, sehingga pada akhirnya dapat membangun opini publik positif dan berdampak terhadap reputasi Blue Bird.
\end{abstract}

Kata kunci : Strategi Public Relations, Manajemen Krisis. 


\section{PENDAHULUAN}

Teringat kembali kejadian pada 22 Maret 2016, demo yang dilakukan atas nama Paguyuban Pengemudi Angkutan Darat (PPAD) di berbagai titik Kota Jakarta, menjadi anarkis dan akhirnya terlibat bentrok dengan pengemudi ojek online. Sekitar 6.000 sopir taksi resmi Jakarta seperti Blue Bird dan Express gelar aksi protes menentang layanan berbasis aplikasi Uber dan Grab, kondisi tersebut membuat macet dan lumpuh kawasan utama ibu kota. Para supir taksi yang demo membawa spanduk menuntut dihentikannya operasi taksi ilegal. Tindakan pengemudi taksi termasuk Blue Bird berlogo "burung biru" itu menjadi anarkis dengan menginjak-injak taksi lain yang tidak mau ikut berdemo. Mereka memukuli pengemudi ojek online dan akhirnya bentrok saling lempar batu dengan massa pengemudi ojek online di jalan protokol Jakarta. Video rekaman tentang supir yang memecahkan kaca taksi lain yang tak ikut demo tersebar cepat di YouTube. Ada juga foto seorang supir taksi dengan seragam biru berpose memegang parang yang berdemonstrasi, tetapi bukan dari serikat pekerja Blue Bird, mereka dari Paguyuban Pengemudi Angkutan Darat," kata Komisaris PT Blue Bird, Noni Sri Ayati Purnomo, di kantor pusat Blue Bird, Warung Buncit, Jakarta. (Liputan6.com, 2016).

Di ingatan masyarakat, selama ini para pengemudi taksi burung biru itu selalu profesional, santun berbicara, ramah pada penumpang, ringan tangan membantu, serta tertib dalam mengendarai mobil. Semua hal baik dari pengemudi sebagai ujung tombak perusahaan itu mendukung reputasi positif dan kredibilitas yang sudah terbentuk puluhan tahun. Masih ingat di tahun kejayaannya, di mana orang hanya percaya dengan nama Blue Bird. Meskipun harga yang ditawarkan lebih mahal daripada merek taksi lainnya, namun mempertimbangkan pelayanan supir, kejujuran, dan keamanan, membuat orang tidak beralih ke taksi lain.

Viral yang beredar di media massa juga turut mendukung reputasi perusahaan taksi yang didirikan pada 1972 ini. Mulai dari barang tertinggal yang dikembalikan oleh penggunanya, sampai kepada argo yang selalu sesuai dan nyaris tidak pernah terdengar terjadi pengalaman buruk dari konsumen. Sayangnya, di hari itu, reputasi dan kredibilitasnya atas pelayanan yang baik, santun, dan ramah, hilang seketika.

Para pengemudi taksi biru yang secara personal berkepribadian santun, rasional, dan sadar, berubah ketika berada dalam kelompok massa menjadi kasar dan irasional. Krisis PR pun terjadi, sang taksi biru mengalami kehancuran, reputasi dan kredibilitas jadi kian menurun. Bad image yang sudah terjadi, kekecewaan masyarakat terhadap merek taksi ternama ini, ada harga yang harus dibayarkan Blue Bird setelah aksi demo anarkis para pengemudi taksi. Reputasi merek (brand reputation) Blue Bird, yang selama ini dikenal sebagai taksi yang nyaman, santun, dan terjamin keamanannya, harus hilang. Rasa antipati itu terekspresikan lewat meme Angry Bird yang tersebar, menggambarkan sang Angry Bird raksasa berwarna biru yang sedang marah di antara kemacetan Jakarta. Logo brand yang memiliki makna "The Bird of Happiness" 
berubah maknanya menjadi "The Bird of Angryness".

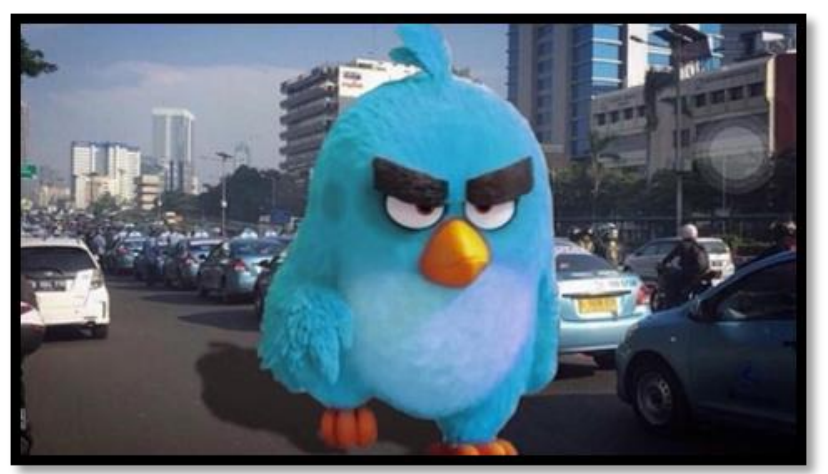

Gambar 1 Tampilan meme Angry Bird Sumber

http://cdn1a.production.liputan6.static 6.com

Krisis memang tidak terduga datangnya. Namun pada saat krisis, perusahaan justru kerap menjadi perhatian media massa. Krisis merupakan peristiwa yang bernilai berita. Pada saat krisis, media massa akan menyoroti perusahaan/organisasi lebih dari pada sebelumnya. (Melly, Jurnal Majalah Ilmiah Unikom, 2013:166).

Pada krisis yang menimpa PT Blue Bird terkait supir taksi Blue Bird yang melakukan demonstrasi, Public Relations bekerja seperti 'pemadam kebakaran' karena tim Public Relations dilibatkan oleh manajemen dalam penangganan kasus demonstrasi tersebut.

Berdasarkan alasan tersebut, penulis tertarik membahas "Strategi Manajemen Krisis Public Relations PT Blue Bird Group". Dengan demikian, diharapkan diperoleh gambaran mengenai bagaimana strategi manajemen krisis PR PT Blue Bird dalam memulihkan citra perusahaan pasca krisis demonstrasi rusuh dan anarkis yang dilakukan oleh para supir taksi Blue Bird pada 22 Maret 2016.

Tujuan yang ingin dicapai penulis dalam mengangkat tema ini adalah ingin memperoleh gambaran mengenai "Bagaimana Strategi Manajemen Krisis Public Relations PT Blue Bird Group".

\section{KERANGKA PENELITIAN}

Crisis management (manajemen krisis) diartikan sebagai suatu praktik yang sedang tumbuh dewasa ini dalam kegiatan hubungan masyarakat (PR) dimana suatu rencana yang rinci telah dipertimbangkan sebelumnya untuk menghadapi setiap kemungkinan krisis yang terjadi dalam batas-batas yang dapat dipahami, seperti misalnya pemogokan karyawan, ledakan bahan kimia, pabrik kebakaran, dan produk yang dihasilkan dibawah standar (Hanson, 2005:56).

Definisi manajemen krisis tersebut merupakan salah satu dari semakin banyak definisi manajemen krisis. Dari definisi itu, diambil beberapa poin dimana (1) semakin hari praktik manajemen krisis semakin dibutuhkan, (2) manajemen krisis merupakan bagian kegiatan PR, dan (3) manajemen krisis merupakan sebuah perencanaan terperinci dalam menghadapi krisis yang menimpa sebuah perusahaan.

Perlunya dilaksanakan manajemen krisis adalah (1) untuk menyiapkan perlindungan yang lebih baik melawan dampak dari krisis, (2) untuk dapat memberikan respon yang efektif terhadap suatu krisis yang sedang terjadi, dan (3) untuk memberikan rencana-rencana dan sumber-sumber untuk penyembuhan dan rehabilitasi setelah krisis terjadi. Besarnya pengaruh pelaksanaan manajemen krisis inilah yang menjadikan PR dituntut untuk 
menjalankan manajemen krisis secara tepat, cepat, dan akurat. Sebuah tuntutan agar dilaksanakannya manajemen krisis yang secara tepat, cepat, dan akurat, dikarenakan manajemen efektif untuk menyelesaikan krisis, juga akan berpengaruh pada corporate image dihadapan publiknya, dan secara otomatis juga akan berdampak pada eksistensi perusahaan di masa yang akan datang (Cutlip, 2000:326).

Menurut Jon White dan Laura Mazur dalam buku Strategic Communications Management: Making public relations work strategic communications management: making public relations work, menyatakan bahwa manajemen krisis tidak sekedar memiliki petunjuk manual, tetapi juga memiliki kemampuan untuk berhadapan dengan sesuatu yang tidak terduga tersebut (krisis) dengan cepat dan respon yang efektif. Pada kenyataannya, memiliki kemampuan untuk berhadapan dengan sesuatu yang tidak terduga tersebut (krisis) dengan cepat dan respon yang efektif. Pada kenyataannya, memiliki sebuah petunjuk yang kaku, justru akan membuat mati kutu. Berkaitan dengan hal ini, Jon White dan Laura Mazur hanya menambahkan bahwa hanya ada petunjuk singkat dalam manajemen krisis, yakni menentukan siapa yang dapat berbicara dengan media, apa yang diperlukan untuk dijelaskan, siapa yang akan berbicara atas nama perusahaan berkaitan dengan permasalahan yang dihadapi, dan seterusnya (White dan Mazur, 1995:206).

Menurut Newsom, Vanslyke, and Kruckeberg, (1996:516-517) mengatakan bahwa ketika krisis terjadi harus segera ditangani. Sebab jika tidak, krisis tersebut akan menghancurkan bisnis perusahaan serta buruknya citra perusahaan, khususnya dimata publiknya.

Pelaksanaan komunikasi saat krisis merupakan syarat utama yang tidak boleh diabaikan oleh perusahaan yang mengalami krisis. Perusahaan yang terus melakukan komunikasi di masa buruk akan menjadi perusahaan pertama yang diingat investor ketika mereka mulai mencari ladang untuk berinvestasi saat kondisi mulai membaik. Pentingnya peran komunikasi saat perusahaan berhadapan dengan krisis, khususnya dalam memperoleh kepercayaan dan dukungan publik. Kepercayaan dan dukungan dari publik ini tidak hanya menunjang kesuksesan perusahaan saat berhadapan dengan krisis, melainkan juga dapat mendukung kinerja dan eksistensi perusahaan setelah krisis berlalu. Peran menjalankan komunikasi saat krisis seperti inilah yang menjadi alasan pentingnya peran PR bagi perusahaan (Richard Barton dalam Majalah SWA No. 24/XXIVI 13-23 November 2008:24-25).

Dalam menghadapi permasalahan mengenai demonstrasi yang dilakukan oleh para supir Blue Bird yang rusuh dan anarkis, Public Relations Blue Bird Group memposisikan perusahaan ke dalam klaster yang ada di dalam Situasion Crisis Communication Theory (SCCT) dan telah memberikan respon krisis dalam penanganan krisis demonstrasi rusuh dan anarkis.

Timothy Coombs dalam Situational Crisis Communication Theory (SCCT, 2007), mengatakan, salah satu Crisis Response Strategy adalah Rebuild Crisis Response dimana perusahaan harus menyatakan permintaan maaf (apology) 
dan bahwa perusahaan bertanggung jawab penuh atas kondisi yang terjadi serta memberikan kompensasi kepada para korban atau pemangku kepentingan yang dirugikan. Selain itu, Coombs juga menjelaskan bahwa orang-orang menjadi prioritas utama ketika krisis terjadi, maka pemberian informasi harus dilakukan terlebih dahulu.

\section{METODE PENELITIAN}

Menurut Pawito

(2008:102)

mengemukakan bahwa dalam pendekatan penelitian kualitatif, kesimpulan yang dihasilkan pada umumnya tidak dimaksudkan sebagai generalisasi, tetapi sebagai gambaran interpretatif tentang realitas atau gejala yang diteliti secara holistik dalam setting tertentu. Di sini, dikandung arti bahwa temuan apapun yang dihasilkan pada dasarnya bersifat terbatas pada kasus yang diamati. Oleh karena itu, prinsip berpikir induktif lebih menonjol dalam penarikan kesimpulan dalam penelitian komunikasi kualitatif.

Berdasarkan tataran atau cara menganalisis data, penelitian ini termasuk dalam jenis penelitian deskriptif. Sejalan dengan hal tersebut, Moleong (2002:11) mengemukakan bahwa salah satu karakteristik dalam penelitian kualitatif adalah deskriptif. Dalam hal ini data yang dikumpulkan berupa kata-kata, gambar, dan bukan angka-angka. Hal ini disebabkan oleh adanya penerapan metode kualitatif. Selain itu, semua yang dikumpulkan berkemungkinan menjadi kunci terhadap apa yang sudah diteliti. Dengan demikian, laporan penelitian akan berisi kutipan-kutipan data untuk memberi gambaran penyajian laporan tersebut.
Data yang diperoleh akan dianalisis secara kualitatif yaitu analisis yang dilakukan dengan memahami dan merangkai data yang telah dikumpulkan dan disusun secara sistematis, kemudian ditarik kesimpulan.

Dalam penulisan jurnal ini, penulis menggunakan jenis penelitian studi kasus dengan model single case study yang hanya membahas pada satu kasus saja yaitu mengenai krisis pada PT Blue Bird yang terjadi akibat para supir Blue Bird melakukan demonstrasi secara anarkis menolak kehadiran transportasi berbasis online yang terjadi pada 22 maret 2016. Masalah yang terjadi pada PT Blue Bird merupakan masalah yang sangat besar, di mana Blue Bird merupakan perusahaan terbesar yang bergerak di bidang transportation services, yang terkenal dengan kualitas pelayanannya. Akibat kasus tersebut harga saham perusahaan pun turun drastis, reputasi dan kredibilitas perusahaan pun hancur seketika. Entah berapa lama waktu yang dibutuhkan manajemen untuk memulihkan kondisi tersebut.

Berdasarkan hal tersebut, maka penulis tertarik untuk membahas mengenai "Bagaimana Strategi Manajemen Krisis Public Relations PT Blue Bird Group pacsa demontrasi 22 Maret 2016"

\section{HASIL PENELITIAN DAN PEMBAHASAN \\ Mengenal PT Blue Bird}




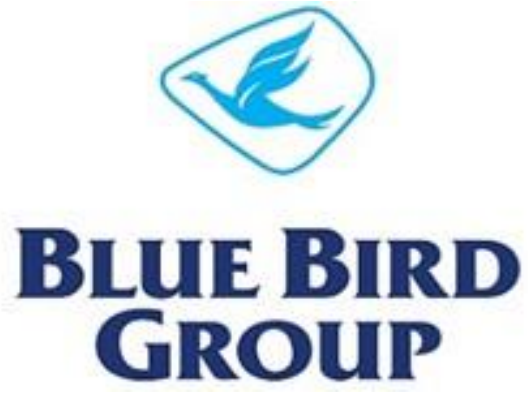

Gambar 2. Logo Blue Bird Group

Sumber :

http://www.bluebirdgroup.com/id/

Blue Bird Group telah berdiri sejak 1972. Dari taksi sampai truk kontainer, Blue Bird Group adalah kelompok usaha yang melayani segala kebutuhan transportasi. Bagi warga Jakarta dan kotakota besar di Indonesia, Blue Bird Group bukan hanya sekadar perusahaan taksi tapi menjadi bagian dari gaya hidup. Jika New York terkenal dengan Yellow Taxi dan London dengan Black Cab, maka Indonesia terkenal dengan Blue Bird armada taksi biru yang selalu menghiasi jalan-jalan di Ibu Kota Jakarta.

Bermula hanya 25 taksi pada 1972, kini armada Blue Bird Group telah mencapai 36.000 armada yang tersebar di sejumlah kota besar di Indonesia. Kini layanan Blue Bird Group dapat dinikmati di Jabetabek, Bandung, Semarang, Banten, Yogyakarta, Solo, Surabaya, Bali, Lombok, Manado, Batam, Medan, Palembang, Padang, dan Pekanbaru.

Melayani lebih dari 8,5 juta penumpang setiap bulannya, Blue Bird Group telah meluaskan spektrum layanannya, mulai dari taksi eksekutif (Silver Bird), layanan limousine dan penyewaan mobil (Golden Bird), bus Charter (Big Bird), hingga truk kontainer (Iron Bird).
Nama Blue Bird terinspirasi dari dongeng Eropa tentang harapan dan doa seorang gadis untuk mendapatkan kebahagiaan yang akhirnya terkabul berkat kebaikan seekor burung biru,"Blue Bird" pun lahir dari sekadar jawaban sebuah doa dan harapan. Ia kini telah berkembang menjadi sebuah perusahaan transportasi terdepan, memenuhi harapan dan cita-cita bukan hanya bagi pendiri, almarhumah Ibu Mutiara Djokosoetono, tapi juga bagi ribuan karyawan.

Pada 1972 jauh sebelum Jakarta berkembang menjadi kota metropolis yang berpenduduk sekitar 12 juta orang, Blue Bird telah hadir. Cikal bakal perusahaan ini yaitu layanan Golden Bird, yang kemudian dikenal sebagai Chandra Taksi. Sebagai sebuah perusahaan penyedia jasa sewa mobil yang khusus melayani para jurnalis asing serta pelanggan lain yang berkunjung ke Jakarta. Berdasarkan pengalaman tersebut, maka tak perlu waktu lama bagi perusahaan untuk mendapatkan izin usaha mengelola taksi.

Awalnya Blue Bird "muda" didirikan untuk menyediakan alternatif jasa transportasi berkualitas yang memang belum ada pada waktu itu. Blue Bird menjadi pelopor pengenaan tarif taksi berdasarkan sistem argo, serta melengkapi seluruh armadanya yang ber-AC dengan radio komunikasi. Selain itu, penggunaan sistem GPS pada armada juga memberikan rasa aman kepada para pelanggannya. Pada 2011, Blue Bird juga menjadi perusahaan taksi pertama di Indonesia yang memberikan layanan mobile reservation melalui BlackBerry. Untuk mempertahankan kualitas pelayanan, perusahaan pun membangun sejumlah bengkel khusus untuk merawat armadanya. 
Setelah lebih dari satu dekade, Blue Bird Group kini memiliki empat divisi utama: Blue Bird, Silver Bird, Golden Bird, dan Big Bird.

\section{Layanan Jasa Blue Bird Group}

Pada layanan transportasi darat, Blue Bird memiliki layanan taksi reguler (Blue Bird Group), taksi eksekutif (Silver Bird), bus carter (Big Bird) dan penyewaan mobil, serta limousine (Golden Bird). Di layanan logistik, layanan Blue Bird Group mencakup Iron Bird Trucking, Iron Bird Transport, Oceanair, dan Ritra Konnas. Sedangkan di bidang industri, Blue Bird Group mendirikan Ziegler Indonesia yang memproduksi karoseri bus dan pusaka Niaga Indonesia sebagai distributor tunggal untuk produk Rossenbauer International yang bergerak dibidang perlengkapan pemadam kebakaran. Blue Bird Group juga merambah bisnis properti, Holiday Resort Lombok Nusa Tenggara Barat dan Pusaka Bumi Mutiara, perusahaan yang khusus mengelola dan mengembangkan seluruh properti dan aset kelompok Blue Bird Group.

\section{Strategi Manajemen Krisis PR PT Blue}

Bird

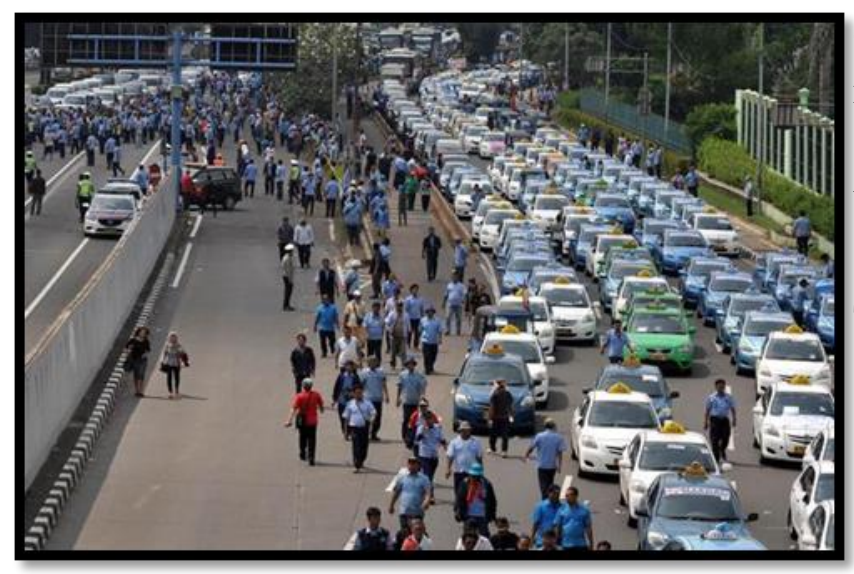

Gambar 3. Demonstrasi supir Blue Bird di Jalan Gatot Subroto
Sumber : http://news.liputan6.com/read

Peristiwa yang menimpa PT Blue Bird mengingatkan kita pada ungkapan populer maestro investasi dunia Warrent Buffett, bahwa butuh 20 tahun untuk membangun reputasi dan lima menit untuk menghancurkannya. Hal ini yang sepertinya disadari oleh Blue Bird, sehingga harus segera menyusun langkah untuk merebut kembali trust konsumen di tengah lanskap bisnis yang telah berubah.

Pentingnya fungsi PR bagi sebuah perusahaan dimana bencana dan krisis menjadi bagian pasti dari bisnisnya. Peran inilah yang kemudian dijalankan oleh Public Relations PT Blue Bird Group. Standard Operational Procedure (SOP) komunikasi krisis yang dilakukan di Blue Bird Group bersifat adaptif dan taktis, dalam hal ini tergantung dari permasalahan yang ada menyangkut divisi yang terkait. Koordinasi dalam manajemen juga bisa bersifat dari bawah ke atas atau atas ke bawah. Koordinasi dari bawah ke atas maksudnya adalah alert/peringatan dari public relations ke manajemen akan adanya krisis dan rekomendasi langkahlangkah yang diambil atau sebaliknya, yaitu adanya arahan dalam bentuk perintah dari top manajemen ke divisi public relations. Selain itu dalam menjalankan SOP krisis, divisi public relations selalu berkoordinasi dengan pihak terkait.

Seperti yang diungkapkan oleh Bapak Teguh Wijayanto :

"saya selaku head of Public Relations dalam menjalankan tugas tidak sendirian. Saya dibantu oleh Pak Andri, kami selalu melakukan koordinasi, karena kami berfungsi sebagai jembatan informasi antara internal ke eksternal maupun 
sebaliknya. Kami juga berfungsi sebagai pembentuk citra positif di mata public. Tugas kami disini sebagai sarana informasi manajemen dan perusahaan, memberikan peringatan dini terhadap sesuatu misalnya krisis. Jika terjadi krisis kami juga memberikan rekomendasi strategi dan langkah apa saja yang harus dilakukan.”

Terkait dengan krisis demonstrasi yang dilakukan oleh supir Blue Bird dipicu oleh penolakan mereka terhadap keberadaan transportasi berbasis online (http://www.antaranews.com/berita/).

Akibat demonstrasi tersebut, reaksi-reaksi yang berdatangan tidak hanya muncul melalui media massa, namun juga muncul melalui media sosial, karenanya aksi demo besar-besaran yang dilakukan oleh Blue Bird itu sendiri menjadikannya memiliki banyak dampak negatif yang diberikan konsumen terhadap Blue Bird. Kejadian tersebut menyebabkan krisis bagi transportasi yang menggunakan lambang burung biru tersebut. Sehingga krisis yang dialami oleh Blue Bird kini masuk ke bagian potensialnya, yakni bukan pengguna Blue Bird. Kebanyakan dari bukan konsumen lambang burung biru itu tampaknya kesal dengan kejadian demo besar-besaran yang dibuat, karenanya demo tersebut membuat kemacetan di berbagai tempat terutama Jalan Protokol Sudirman-Semanggi, Slipi, hingga Kantor DPR.

Dalam menghadapi permasalahan mengenai demonstrasi yang dilakukan oleh para supir Blue Bird yang rusuh dan anarkis, Public Relations Blue Bird Group memposisikan perusahaan ke dalam klaster yang ada di dalam Situasion Crisis Communication Theory (SCCT) dan telah memberikan respon krisis dalam penanganan krisis demonstrasi rusuh dan anarkis. Timothy Comb dalam Situational Crisis Communication Theory (SCCT, 2007), mengatakan, salah satu Crisis Response Strategy adalah Rebuild Crisis Response dimana perusahaan harus menyatakan permintaan maaf (apology) dan bahwa perusahaan bertanggung jawab penuh atas kondisi yang terjadi serta memberikan kompensasi (compentation) kepada para korban atau pemangku kepentingan yang dirugikan.

Oleh karena itu, peran seorang PR yakni sebagai fungsi komunikasi untuk mengembangkan komunikasi institusi dengan publik agar berjalan dengan baik untuk mewujudkan goodwill dan mutual understanding terhadap publik, oleh karenanya Blue Bird menggratiskan layanan agar tercipta pemahaman yang baik dan mengembalikan nama baik Blue Bird dan mewujudkan mutual understanding terhadap tujuan, kebijakan, dan kegiatan dari perusahaan Blue Bird. Selain itu, aktivitas yang digunakan juga merupakan bagian dari komunikasi internal dan eksternal.

"Kami menjalin hubungan baik dan membina hubungan dengan publik internal maupun eksternal; internal misalnya dengan manajemen dan karyawan, kemudian untuk eksternal kami menjalin hubungan baik dengan media, komunitas dan blogger/netizen. Kami disini sebagai penasehat manajemen, pemberi rekomendasi, fasilitator komunikasi dan memacahkan masalah." Tutur pak Teguh Wijayanto.

Dalam penangganan krisis yang di alami oleh Blue Bird, pak Teguh Wijayanto selaku Head of Public Relations 
juga menjelaskan mengenai koordinasi ketika krisis itu terjadi:

"dalam menghadapi krisis, kami berdiskusi, mencari data dan fakta. Kemudia kami juga meminta mendapat dari Vice President Operations (Bapak Agus Sulistiyono), selanjutnya kami membahas krisis, strategi dan taktiknya kepada Ibu Noni Purnomo dan Bapak Purnomo Prawiro selaku direktur utama dan pemberi keputusan."

Maka pada 22 Maret 2016, Komisaris

Utama Blue Bird sekaligus salah seorang putri sang pemilik, Noni Sri Aryati Purnomo menyelenggarakan press conference dimana konten press conference berisi permohonan maaf dan janji menggratiskan layanan taksi Blue Bird selama satu hari setelah aksi kepada seluruh pelanggan di wilayah Jabodetabek. Menggratiskan Blue Bird selama satu hari adalah bentuk dari komunikasi internal dan eksternal untuk memperoleh umpan balik dari konsumen atau pengguna Blue Bird dan sebagai bentuk menyampaikan citra yang baik terhadap pelanggan atau konsumen.

Selain memberikan kompensasi gratis taksi Blue Bird selama satu hari, Public Relations Blue Bird juga memanfaatkan komunikasi digital sebagai pusat komunikasi dan krisis. Sehingga mampu membangun komunikasi yang engage langsung kepada publik. Public relations juga harus mampu mengomunikasikannya dengan memanfaatkan media sosial sebagai media komunikasi dengan konsumen, karyawan, dan masyarakat umum, khususnya warganet sebagai publik yang memegang kunci komunikasi. Sehingga pada akhirnya membangun opini publik positif dan berdampak terhadap reputasi Blue Bird.

Blue Bird merupakan "kapal besar" dengan jumlah karyawan mencapai 45.000. Sebagai suatu organisasi besar, tantangan terbesar dalam melakukan perubahan adalah komunikasi internal, sehingga di tengah percepatan perputaran roda ekonomi dan perubahan teknologi di dunia Blue Bird bisa tetap agile, tetap dinamis dalam menghadapi perubahan, dan cepat dapat pula diadaptasi oleh para pengemudi yang notabene grassroot dan ambassador dari brand Blue Bird.

Komitmen Blue Bird untuk berubah salah satu strategi manajemen krisis dilakukan dengan program "reimagining Blue Bird" yang disuarakan melalui iklan kampanye Blue Bird "Berbenah untuk Berubah" di YouTube yang diunggah pada 25 September 2016 lalu. Video berdurasi dua menit itu berhasil menyedot perhatian publik, khususnya warganet. Hingga 28 Februari 2017 lalu video tersebut telah ditonton sebanyak 115.354 kali (https://www.youtube.com/watch).

Dalam video tersebut, perusahaan Blue Bird mau mengakui kesalahan dan menegaskan berkomitmen untuk berubah mengikuti perkembangan zaman.

“.... Beri kami kesempatan, karena kami ingin bersama-sama ikut pertandingan. Kami sedang berbenah, karena kami ingin berubah." (pesan yang disampaikan oleh Blue Bird dalam kampanye Blue Bird "Berbenah untuk Berubah"). 

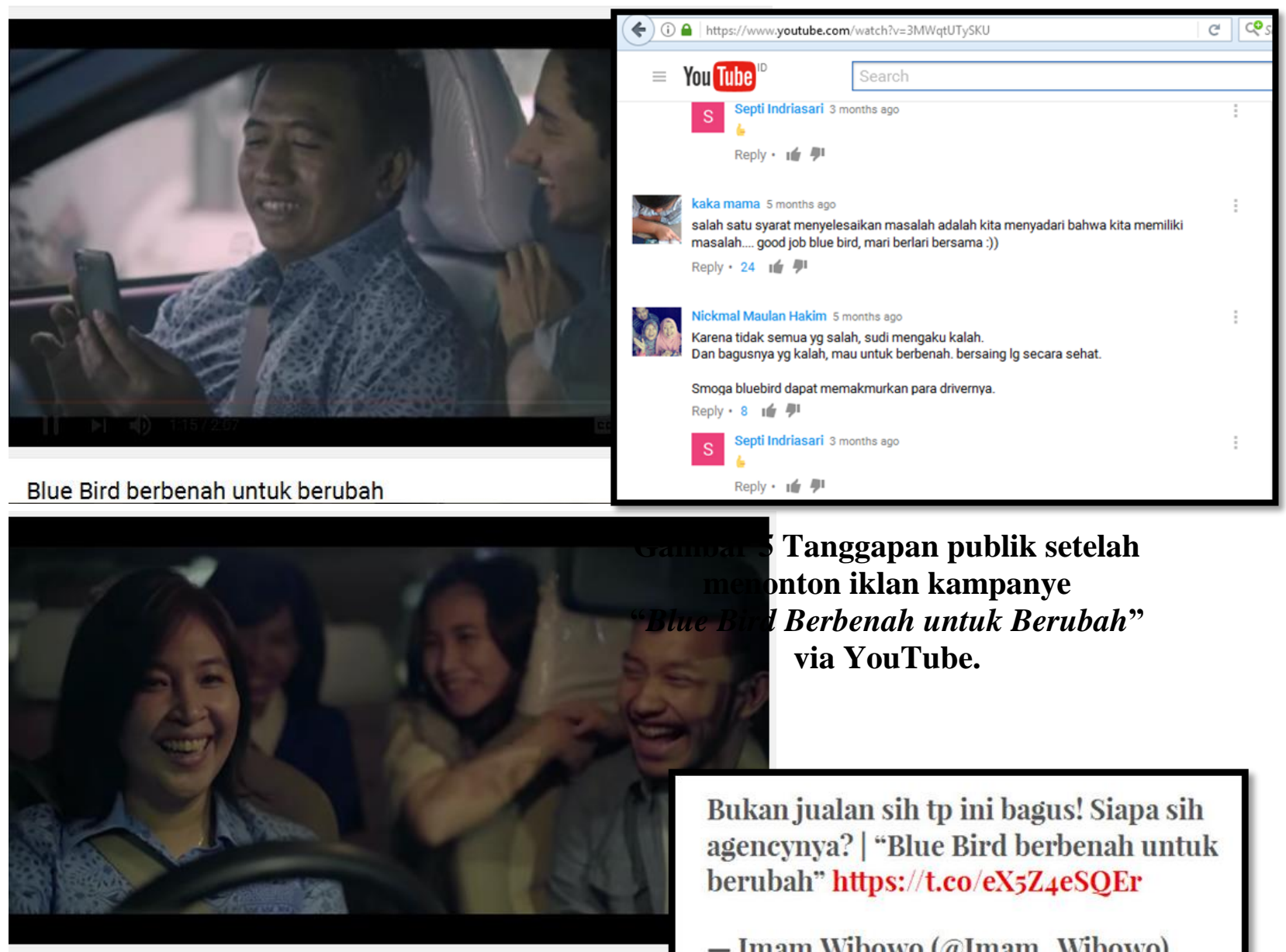

Blue Bird berbenah untuk berubah

Tanggapan publik setelah pnton iklan kampanye Berbenah untuk Berubah" via YouTube.

Gambar 4 Tampilan kampanye Blue Bird "Berbenah untuk Berubah".

Dalam video digambarkan bahwa para pengemudi Blue Bird sedang memberikan pelayanan yang baik, ramah, dan sopan kepada pihak konsumen.

Sumber :

https://www.youtube.com/watch

\section{Gambar 6. Tweet yang berisi pujian terhadap video kampanye Blue Bird.}

Video kampanye Blue Bird "Berbenah untuk Berubah" dikeluarkan guna menyampaikan pesan kepada internal (pengemudi) dan eksternal. Secara internal, narasi iklan yang sangat menyentuh disampaikan langsung oleh Noni Purnomo CEO Blue Bird Group 
Holding mengajak seluruh keluarga besar Blue Bird untuk melakukan perubahan lebih cepat. Secara eksternal, CEO menegaskan bahwa Blue Bird selama ini sudah ada di hati para konsumennya. Dengan adanya program "reimagining Blue Bird", perusahaan Blue Bird berharap bahwa Blue Bird dapat terus relevan dengan era kekinian tanpa mengubah jati dirinya, Sehingga, pada akhirnya Blue Bird Group mampu membangun opini publik positif yang berdampak terhadap reputasi perusahaan.

\section{KESIMPULAN}

Mengelola reputasi memang bukan pekerjaan mudah. Mengelola krisis juga tak bisa sekadar tampil di media tanpa strategi public relations yang komprehensif, tepat, dan cermat. Krisis bisa terjadi kapan saja, dimana saja, kepada siapa saja. Tidak ada perusahaan, bagaimanapun kuat finansialnya, bagaimanapun kuat reputasinya yang kebal terhadap krisis. Hal inilah yang pernah terjadi dan dirasakan oleh perusahan Blue Bird Group, demonstrasi anarkis oleh para pengemudi taksi, salah satunya mereka yang berseragam Blue Bird, sudah terlanjur beredar. Caci maki masyarakat sudah telanjur menyebar di dunia maya. Berbagai media nasional, termasuk online, turut menjadikan aksi anarkis oknum pengemudi berseragam "burung biru" itu sebagai bahan berita yang hangat pada saat itu (22/3/17). Oleh karena itu dibutuhkan penanganan yang sangat cepat oleh public relations atau tim manajemen krisis Blue Bird Group.

Berdasarkan hasil penelitian dapat diambil kesimpulan bahwa dalam mengatasi krisis yang terjadi pada PT Blue
Bird Group, strategi yang dilakukan oleh Public Relations yaitu dengan membuat program kampanye "reimagining Blue Bird" dengan tema "Berbenah Untuk Berubah" yang disuarakan melalui YouTube. Program Kampanye "Berbenah untuk Berubah" PT Blue Bird Group Tbk, yang diunggah melalui YouTube, dapat dikatakan berhasil karena telah membuat persepsi atau opini yang positif pada publik bahwa taksi Blue Bird mengakui mereka lamban menerima perkembangan zaman dan ingin melakukan perubahan dengan cara berbenah diri dalam mengikuti perkembangan zaman, sehingga menimbulkan suatu sikap dan citra yang positif di benak publik.

Dan dari video kampanye Blue Bird "Berbenah untuk Berubah" memberikan pesan bahwa mereka tetap terus berkomitmen dalam memberikan pelayanan yang terbaik kepada publiknya dengan mengikuti perkembangan era digitalization. Pada video kampanye tersebut, pihak manajemem dalam hal ini Ibu Noni Purnomo selaku Direktur Utama PT Blue Bird meminta maaf kepada publik. Permintaan maaf tersebut ternyata telah berhasil menarik perhatian dan mendapatkan simpati dari publik. Publik berharap agar penyelenggara transportasi terbesar ini akan memberikan service yang lebih baik, sehingga pada akhirnya dapat membangun opini publik positif dan berdampak terhadap reputasi Blue Bird.

\section{UCAPAN TERIMA KASIH}

Penulis mengucapkan terima kasih kepada Bapak Teguh Wijayanto selaku Head Of Public Relations PT Blue Bird yang telah membantu penulis dalam proses pengumpulan data. 
https://www.youtube.com/watch?v=3MW qtUTySKU(di akses tanggal 25 Februari 2017)

Majalah SWA No. 24/XXIVI 13-23

November 2008.

\section{DAFTAR PUSTAKA}

Coombs, Timothy W. 2007. Crisis

Management and Communication.

Cutlip, Scott M; Center, Allen H; Broom, Glen M. 2000. Effective Public Relations. New Jersey: Prentice Hall. Kriyantono, Rachmat. 2006. Teknik Riset Komunikasi. Jakarta: PT Rajagrafindo Persada.

Moleong, Lexy, J. 2002. Metode Penelitian Kualitatif. Bandung: PT Remaja Rosda Karya.

Pawito. 2008. Penelitian Komunikasi Kualitatif. Yogyakarta: LKIS Pelangi Aksara.

Ruslan, Rosady. 2010. Metodologi Penelitian Public Relations dan Komunikasi cetakan ke-5. Jakarta: Rajawali Pers.

Suryabtara. Sumadi. 2011. Metode Penelitian. Jakarta: Raja Grafindo Persada.

\section{Jurnal :}

Purwaningwulan. Melly. Maulin, Jurnal Majalah Ilmiah Unikom, Fakultas Ilmu Sosial dan Ilmu Politik Universitas Ilmu Komputer, Bandung, Volume 11 No. 2, Tahun 2013.

\section{Sumber lain:}

http://www.bluebirdgroup.com/id/ akses tanggal 24 Februari 2017)

http://www.antaranews.com/berita/551305 /demo-jeda-supir-taksi-vs-pengemudigojek-hampir-rusuh(di akses tanggal 20 Februari 2017)

http://cdn1a.production.liputan6.static6.co m/medias/1178845/big/080663700_14586 22272-2x.jpg(di akses tanggal 20 Februari 2017) 